\title{
Problematising Tribality: A Critical Engagement with Hansda Sowvendra Shekhar's The Adivasi Will Not Dance: Stories
}

\author{
Francis Ekka ${ }^{1} \&$ Dr. Rosy Chamling ${ }^{2}$ \\ 'Research Scholar, Department of English, Sikkim University. \\ Email id: fekka.2ompeno1@sikkimuniversity.ac.in, ekkafran@gmail.com. ORCID id: oooo-ooo2- \\ 2777-3121. \\ ${ }^{2}$ Associate Professor, Department of English, Sikkim University. \\ Email id: rchamling@cus.ac.in. ORCID id: oooo-0oo2-4936-4767.
}

\begin{abstract}
Tribality simply means the characteristic features of various tribal communities and the qualities of being tribal. In the 1940s leading anthropologists like Verrier Elwin and G.S.Ghurye tried to theorize and categorize tribal identities. However, they were often accused of representing either a 'protective' or 'romantic' notions of tribality. One cannot determine the tribality of a person based on their features, dialects, food habits or geographical location. Tribality is said to bind the pan-Indian Tribal literature which is again problematic considering language which is considered as the useful indicator of any identity. Tribal Literature is a distinct form of writing to represent people, things and ideas in their cultural authenticities. The tribals essentially have an oral culture and thus when a tribal writer like Hansda Sowvendra Shekhar, a Government Doctor by profession, writes in the canonical English language, we will be tempted to probe if he seeks to 'write in' or 'write back' to the mainstream literary culture; or if his works can fit into the mould of minor literature, thereby making the seemingly personal an intensely political statement. This paper also aims to interrogate issues of tribal identity and their representation through a critical engagement with Hansda Sowvendra Shekhar's The Adivasi Will Not Dance: Stories (2017).
\end{abstract}

Keywords: Adivasi, Tribality, Identity, Representation, Minor Literature

\section{Introduction}

Tribality simply means the characteristic features of various tribal communities and the quality of being tribal. In the 1940s leading anthropologists like Verrier Elwin and G.S. Ghurye tried to theorize and categorize tribal identities. However, they were often accused of representing either a 'protective' or 'romantic' notions of tribality. One cannot determine the tribality of a person based on their features, dialects, food habits or geographical location. Tribality is said to bind the panIndian Tribal literature which is again problematic considering language which is considered as the useful indicator of any identity. Tribal Literature is a distinct form of writing to represent people, things and ideas in their cultural authenticities and there seems to be difficulty in making it fit into the rubric of third world literature. In order to join the dots of tribal literature it is necessary to understand tribality or the philosophy around tribality. Tribality is also often confused with indigeniety. There is a thin line that separates these two terms from one another. Indigeniety is something that is occurring naturally in a place; the autochthonous or the original inhabitant of a place, whereas, tribality is the characteristic features of a tribal. A Sydney based thinker, Anita Haes, has said that "the tribality of the tribals can neither be classified nor measured against any standard This Open Access article is published under a Creative Commons Attribution Non-Commercial 4.0 International License (http://creativecommons.org/licenses/by-nc/4.0/), which permits non-commercial re-use, distribution, and reproduction in any medium, provided the original work is properly cited. For citation use the DOI. For commercial re-use, please contact editor@rupkatha.com. 
because it is a quality that is part of your heritage and can neither be denied nor rejected. You cannot determine the tribality of any person on the basis of whether tribal blood flows in their veins" (Gond, 2017). The tribals essentially have an oral culture and thus when a tribal writer like Hansda Sowvendra Shekhar, a Government Doctor by profession, writes in the canonical English language, we will be tempted to probe if he seeks to 'write in' or 'write back' to the mainstream literary culture; or if his works can fit into the mould of minor literature, thereby making the seemingly personal an intensely political statement

Of late there has been a surge in the discourses of tribal studies. This could possibly because of years of exploitation and deprivation inflicted upon the tribals due to the lop-sided economic development practices of the Government. Tribal literature is imbued with this tribal consciousness, the desire to articulate the angst of living in the margins and the desire to carve out their distinct identity against the mainland culture. The policy of economic liberalization and market economy adopted by the Government of India in the 1990s saw a slew of development projects which led to displacement and exploitation of the tribals. The tribals were stripped of their right to land, forest, water and other natural resources and even their right to self-determination. Tribal literature seeks to make this angst heard and this is possible because of authors like Hansda Sowvendra Shekhar who are writing in English and being published by major publishing houses.

\section{Problematising Tribality}

Hansda Sowvendra Shekhar is a Doctor employed in a Government Primary Hospital in Pakur, a remote area in Jharkhand. Being a Santhali tribal, he gives us an insider's account of tribal world view through a raw and sensitive depiction of tribality. Hansda is the winner of Sahitya Akademi Yuva Puraskar in English (2015) and the joint winner of the Muse India-Satish Verma Young Writer Award (2015). Besides being a practicing doctor, Hansda has published many works in English. He is the most celebrated writer of Santhali community and adivasis at large. His book The Adivasi Will Not Dance: Stories (2017) established Hansda Sowvendra Shekhar as one of the most promiment writers of tribal literature in contemporary times. Through this book, he not only provides us with an insider perspective but gives us a voluminous account of the plight of adivasis across India. The very act of assertion through the line "the adivasi will not dance" in the title of his collection of short stories is the voice of the subaltern who is trying to defy and resist mainstream culture. When asked about the title, Hansda had replied in the Sunday Guardian Live:

I chose to name my story "The Adivasi Will Not Dance" as an act of defiance. Adivasis are made to dance at government functions, are made to entertain VIP guests, but what do they get in return? Adivasis are among the major casualties of all the development programmes of the governments, be it roads, dams, power plants, or any factory or industry for that matter. So what might happen if Adivasis refuse to dance at a government programme, which has been organized to lay the foundation stone of a thermal power plant which would, again, displace several Adivasis from their villages?...The title does not say that the Adivasis refuse to dance or sing altogether, because an Adivasi community cannot be imagined without music and dance. It says that Adivasis refuse to be forced into singing and dancing against their will. (June 17, 2017)

The tribal population of India is relatively large and live in close approximation to the world of nature. The tribals live in close unison with one another and as such there is actually no private versus public dichotomy in their lives. Their communal ways of living with an inherently rich oral culture is a distinct identity marker. Their language and dialect also distinctively set them apart 
from the mainstream culture. Devy in his introduction to Painted Words: An Anthology of Tribal literature (2002, pp. ix-x), says that "it is impossible to characterize a tribal identity by any single distinguishing feature...." He also says that the useful indicator of a tribal identity is their language. Most of the tribal epics, arts, legends and their stories remained spoken and recent advances in language and gaining of scripts making tribal writers thrive and pen down the various events and stories. Globalization has hit hard so much so that even tribal writers are applying mainstream medium to further their cause. This can lead to the danger of contamination of tribal consciousness because there may not be an appropriate word to translate that tribal sensibility. This also kind of takes us back to the debate on language started by Ngugi wa Thiong'o and Chinua Achebe concerning African literature. This paper will obviously not touch the part of colonial consciousness and rather it will show the cultural demarcation created. Tribal Literature in India is written in various mainstream, regional and tribal languages that obviously has nothing to do with colonial consciousness. However, English language does carry colonial baggage with it but in this context it is different case altogether. In this context English language is applied as no less than just a medium as equal to Hindi or any other regional languages. Ngugi wa Thiog'O and Chinua Achebe were certainly concerned for the representation of their various ethnic communities. Both seem to have their own sets of principles for justifying their medium. The debate of language seems dense and layered. However, both Ngugi and Achebe have expressed their views on language extensively. In his On Writing in Gikuyu (1985, p. 151), Ngugi argues that:

An African should write in a language that will allow him to communicate effectively with peasants and workers in Africa; in other words, he should write in an African language.... Literature published in African languages will have to be meaningful to the masses and therefore much closer to the realities of their situation. (Mbele, 1992, p. 147)

Contrastingly, Achebe writes:

I feel that the English language will be able to carry the weight of my African experience. But it will have to be a new English, still in full communion with its ancestral home but altered to suit new African Surroundings. (Thiong'O, 1994, p. 436)

This contrasting arguments of Ngugi and Acebe have nothing sort of foundational effect in tribal literature of India. But both the arguments depict some sort of similar circumstances while problematising tribality. If language is the indicator of a tribal identity but when that same language is replaced by other mainstream major language an overtly political statement is being made. An Adivasi writer like Hansda Sowvendra Shekhar perhaps 'writes in' English language to 'write back' to the major literary readership and thereby exposing the 'impossibility' of conveying the Adivasiness.

The Adivasi Will Not Dance: Stories (2017) is no less than a collection of ordinary yet fascinating tales. What makes it distinct is probably the community, the culture and the class of the people that have not been ably represented or under-represented in the mainstream majoritarian culture. Each of these stories bear contamination of the personal with the political and against such engagement any "individuated enunciation" becomes impossible. Hansda Sowvendra Shekhar, being a Santhali himself, unapologetically brings forth the events and practices and mainly the Santhali characters into life through this collection of poignant tales. The Santhali community share a rich and magnanimous traditions and culture and a language that constitutes them as a distinct tribe. The Adivasi Will Not Dance: Stories (2017) is a collection of ten short stories. Each story has a different touch and altogether different nuances. What really binds the stories together 
is Shekhar's unique proclivity of standing out and delivering an unapologetic expression of his experiences in a fictionalised characters and manners. As for the quality of being a tribal, Shekhar highlights all of the qualities of tribal identity conformity in this collection. In "They Eat Meat" the first story from the collection, Shekhar talks about conforming to the norms of the society in Vadodara. The title of the story "They Eat Meat" is aptly suggestive that being a tribal in the neighbourhood vicinity of the non-tribals. At the very beginning of the story when the Soren family move to Vadodara, Mr. Rao, the landlord clearly accuses them of being a tribal: "Er...Isn't Soren a tribal surname?..." (Shekhar, 2017, p.5). As obvious as it seemed, Biram Soren "was shocked at being asked this directly..." (p. 5). Mr, Rao, the landlord contritely adds: "Tribals, even lower-caste Hindus, they are seem as impure. I hope you understand" (p. 6). This very notion of seeing tribality as something impure is probably what raises the question of a tribal identity. What constitutes tribality? What are the various parameters of marking the tribal as an outsider? As far as the position of Mr. Rao and Biram Soren is concerned, they are both employees of a government enterprise. The very notion of tribality itself is problematic here. This problem of tribality is no less than any kind of racial prejudice.

After setting the tone of debate on tribality as something impure, Shekhar goes on to explore some serious issues and events in the later stories. While touching on various issues and events, Shekhar make sure to highlight the various notions around tribal identity. For instance, in the story "Sons" Shekhar, while making comparison between the two sons of Kalpana-di and Vidya-di, Suraj and Raghu respectively, showing their bitter-sweet passage to life and also Kalpana-di's husbands and sons corrupted and unscrupulous dealings, he asserts how Adivasis are being used by people from elite class or people in powerful positions:

We Adivasi are very bad at stealing. Corruption isn't in our blood. And even if we do commit a crime, we are pathetic at covering our tracks. Don't you see what happened to Madhu Kora? He was used by the Dikus and left alone to suffer a jail term. This should be a lesson for all of us". (p. 32)

In another instance, in the story "November is the Month of Migrations" while exploring on the issue of Sathalis migrating to other districts and states in search of employment, Shekhar unapologetically highlights how the Diku, who represents the people in powerful position, the policeman uses bread pakora and fifty-rupee note to lure Talamai to have sex, who was also waiting for the train to Namal in search of work. It was for sure that out of hunger and in need of money, Talamai submits herself to the Diku policeman. Talamai was also aware that other girls of her age did indulge themselves in this kind of activity in exchange of something in return: "She knows many girls who do that work with truck drivers and other men. And she knows that on their way to Namal, Santhal women do this work for food and money at the railway station, too" (p. 40). What Shekhar is trying to explore here is that tribal people are easily exploited and used for their innocence, deprivation and poverty in the hands of the powerful class. Tribal women are identified as mere sex objects: "Saali, you Santhal women are made for this only. You are good!" (p. 41)

Amongst the tribal groups, there is some sort of reprisal "just for the warring parties to get even with each other". We witness this in the story "Getting Even" where a ten year old boy is accused of raping a four year old girl. The boy's family claimed that their son has done nothing wrong. It seemed that the victim's party is taking revenge on them because they sold their daughter in Delhi and that the boy's family rescued her and brought her back. While Shekhar also claims the reality at the end of the story: 
In the meanwhile, in the Santhal Pargana, so many Santhal girls will have been sold, so many Santhal boys implicated on false charges, so many FIRs filed in police stations, just for the warring parties to get even with each other. (p. 57)

We get another instance of tribality as 'impure' in the story "Eating with the Enemy", where Sulochana shrank back in horror when she was asked by the owner where she worked as a house maid to wash the cups of the workers who were all Santhalis from nearby villages. Here Sulochana is herself a Ghaasi caste, who worked mostly in the Bengali houses which had given her a superior demeanour. Sulochana does not know that this was the only Santhal, in fact the only Adivasi house. There are other stories in the collection, for instance, the story of Suren and Gita who were waiting for their blue baby to turn pink outside the neo-natal ward; the story of Baso-jhi from the village Sarjomdih who was accused of practicing black magic when people were dying for no apparent reason; and other such stories depicting normal day-to-day life, relationships, desires, deaths, witchery, and stories from the red light areas, all jostle with life and attention in the pages of this short story collection. Shekhar, here, is giving us an insider perspectives on how tribality is often confused and considered based on what a tribal does.

\section{Adivasi Literature as Minor Literature}

It is by virtue of its tribality that Adivasi Literature can be considered as 'minor literature' because the privileging of writing over the Adivasi oral tradition has not only given it a 'minority' status but also one that uses the mainstream language to critique the majoritarian worldview. Deleuze and Guattari have said that minor literature is a literature of 'becoming', which is in a constant process of creating something anew whereby the 'subject group' creates its own distinct identity. Deleuze and Guattari have laid down three basic premises of minor literature in Kafka: Toward a Minor Literature: "A minor literature doesn't come from a minor language it is rather that which a minority constructs within a major language. But the first characteristic of minor literature in any case is that in it language is affected with a high coefficient of deterritorialization" (Kafka: Toward a Minor Literature, 2003: 16). Drawing from Kafka who was a Czech speaking Jew but who wrote in the German language, we have here Sowvendra Shekhar an Adivasi writing in English, the language of India's elite. Being a doctor by profession and a story teller by passion, Shekhar has access to wide spectrum of knowledge of people and their stories as an insider. He travels from reality to fiction, from hospital to outside world through a play of magic realism. He nonchalantly problematises them by showing that the tribal characters are expected or taken to be poor, innocent, foolish, deprived, uneducated, subaltern, and are not capable to stand or speak for themselves and largely remain marginalised. Hansda Sowvendra Shekhar has effortlessly portrayed Santhali characters and matters and breathed life into them through ample use of the vernacular Santhali language. Many a time, his writings are taken to be political but his narration, style, themes and characterisation is so unique that in highlighting unusual concerns and people his literary style and approach stands out from the mainstream majoritarian culture.

Shekhar's voice is powerful, political, and urgent; which brings us to the second premise of minor literature: "The second characteristic of minor literature is that everything in them is political. In major literatures, in contract, the individual concern (familial marital, and so on) joins with other no less individual concerns, the social milieu serving as a mere environment as a background; this is so much the case that none of these oedipal intrigues are specifically indispensable as absolutely necessary but all become as one in a large space. Minor literature is 
completely different; it's cramped space forces each individual intrigue to connect immediately to politics. The individual concern thus becomes all the more necessary, indispensable, magnified, because a whole other story is vibrating within it" ( Kafka: Toward a Minor Literature, 2003: 17). Shekhar highlights the deplorable condition of the tribals in his book; their lands are being seized in the name of development by coal merchants and stone merchants which leave them with nothing but- "Tatters to wear. Barely enough food. Such diseases that we can't breathe properly, we cough blood and forever remain bare bones"(p. 172). As far as Shekhar's narrative is concerned, tribals are merely seen as savages and brutes. "Kiristan" asks them to stop following Sarna religion and to worship "Jisu" and rename Santhal names from Hopna, Som, Singrai to David and Mikail and kiristofer. When Hindus and Muslims intended to offer them help then the Santhals were asked to stop eating meats like beef and pork and also asks them to stop drinking "haandi". From what is clear, different religion acted as the colonial power that saw the Santhals as savages and they were offering help to make them civilize. But in doing so, Shekhar claims that: "We are losing our Sarna faith, our identities, and our roots. We are becoming people from nowhere"(p. 173).

Shekhar also claims through Mangal Murmu that there is no powerful Santhali voice. There is no powerful voice to speak for their cause or to retaliate back at their predicament, and when a writer like Hansda Sowvendra Shekhar writes to echo the collective angst of the Adivasi tribes which is reminiscent of the third characteristic of minor literature: "The Third characteristic of minor literature is that in it everything takes on a collective value. Indeed, precisely because talent isn't abundant in a minor literature, there are no possibilities for an individuated enunciation that would belong to this as that "master" and that could be separated from a collective enunciation. Indeed, scarcity of talent is in fact beneficial and allows the conception of something other than a literature of masters; what each author says individually already constitutes a common action, and what he or she says or does is necessarily political, even if there aren't in agreement. The political domain has contaminated every statement" (Kafka: Toward a Minor Literature, 2003: 17). Of all the stories, the final and the title story "The Adivasi Will Not Dance" is what serve as Shekhar's manifesto to assert defiance and problematises tribality. The story highlights the displacement of Adivasi people from Godda where the government plans to build the power plant. The protagonist, Margal Marmu, a musician, and his troupes are invited to perform in the inaugural ceremony. But after learning about the displacement of Adivasis from around eleven villages, Mangal Murmu asserts and exclaims in front of the chief guest, the President of India that the adivasi will not dance. The troupe-master Mangal Murmu is beaten down for refusing to perform. Throughout the story, Shekhar expresses through the protagonist of the story, Mangal Murmu, that Adivasis are a gullible lot. They are easily used and fooled by the Dikus and other powerful people: "But we Santhals are fools, aren't we? All of us Adivasis are fools. Down the years, down generations, the Diku have taken advantage of our foolishness. Tell me if I am wrong" (p. 170). It is true to admit that tribals are used like toys, exploited and displaced from their lands, denied access to power and positions. Tribals are taken as no less than mere automaton:

We are like toys- someone presses our 'ON' button, or turns a key in our backsides, and we Santhals start beating rhythms on our tamak and tumdak, or start blowing tunes on our tiriyo while someone snatches away our very dancing grounds. Tell me, am I wrong? (p. 17o)

This surely implies Spivak's assertion or rather the imperative question- "can the subaltern speak?' Spivak in her essay "Can the Subaltern Speak?" argues that since the subaltern people are always represented by the elite class and so they are never truly heard or given chances to speak for themselves. They are deprived of their essentialism and their existentialism. Spivak also highlights the ancient practice of self-immolation (sati) of women and how the colonial agents serve as the 
saviour by claiming to save the brown women from brown men. This signifies the powerless position of a subaltern woman. She has no right to give her opinion whether she wants to be saved by the elite group or get burned by the men from her own group. Either way, she is at the margins (Spivak, 1988). This instance is similar to the observation made by Hansda Sowvendra Shekhar in his title story of the book The Adivasi Will Not Dance: Stories (2017). The Adivasis are always at the margins of mainstream society. Their lives and lands are at stake either on the hands of the government or on some powerful and elite class. Their marginality is being threatened by the majoritarian culture which seeks to render them as mere tools for furthering their self-interest. There are "no shouters, no powerful" Adivasi voices to speak on behalf of the Adivasi community. "We Santhals do not know how to protect our riches. We only know how to escape"(p.176). They are being under represented or hardly represented at all by the mainstream majoritarian culture. And the very assertion that "the adivasi will not dance" is a sort of resistance to this mainstream culture. The tribals are often approved or revered for their art. The Santhals are good at their art, music and dance and they consider them very sacred. "Yet", the question is- "what has our art given us? Displacement, tuberculosis"(p. 178). The monologue by Mangal Murmu at the end of the story kind of sums up the defiance that how can they dance and be happy when their people are being displaced and has no place to go or to grow crops.

Johar, Rashtrapati-babu. We are very proud and happy that you have come to our Santhal Pargana and we are also very proud that we have been asked to sing and dance before you and welcome you to our place. We will sing and dance before you but tell us, do we have a reason to sing and dance? You will now start building the power plant, but this plant will be the end of us all, the end of all the Adivasi. These men sitting beside you have told you that this power plant will change our fortunes, but these same men have forced us out of our home and villages. We have nowhere to go, nowhere to grow our crops. How can this power plant be good for us? And how can we Adivasis dance and be happy? Unless we are given back our homes and land, we will not dance. We Adivasi will not dance. The Adivasi will not... (p. 187).

\section{Conclusion}

Thus it is clear that Hansda Sowvendra Shekhar has aptly portrayed the nuances of tribal sensibility in a canonical language of the mainstream, which is English. Although there are misgivings expressed by scholars like Sukalpa Bhattacharjee "But will the rubric "Tribal Literature" fit into the postcolonial descriptive categories like "Third World Literature" or "Indian Literature" or will this term make up for the in-between in "post" and "colonial"? Or will it be the "blank space" of postcolonial literature in the sense of unidentified and unexplored peoples and regions?" (Man and Society, Vol.VIII, 2018); it is indeed difficult to find an apt category to provide for a normative or conceptual framework for tribal sensibility. Writer-activist Mahasweta Devi, who has lived closely with the tribals says, "The tribal and the mainstream have always been parallel. There has never been a meeting point. The mainstream simply doesn't understand the parallel...", signifying how tribality is more a consciousness that refuses to be categorized into normative or rigid frameworks. In fact, Hansda Sowvendra Shekhar's works bear marks of 'minor literature' whereby using the language of the majoritarian, the young talented Adivasi writer has showcased the collective enunciation of the Adivasis at large. 


\section{References}

Achebe, C. (1975). The African Writer and the English Language. Morning Yet On Creation Day (pp. 103). London.

Chakraborty, A. (2019). Problematising 'Indigeneity' through Hansda Sowvendra Shekhar's The Mysterious Ailment of Rupi Baskey. Rupkatha Journal on Interdisciplinary Studies in Humanities, 11(3). https://doi.org/10.21659/rupkatha.viın3.19

Deleuze, G., \& Guattari, F. (2003). Kafka: Toward a Minor Literature ( $7^{\text {th }}$ ed.). (D. Polan, Trans.). Minneapolis: University of Minnesota Press.

Devy, G. N. (2007). A Nomad Called Thief: Reflections on Adivasi Silence (2 ${ }^{\text {nd }}$ ed.). Delhi: Orient Longman.

Devy, G. N. (2002). Painted Words: An Anthology of Tribal Literature. Penguin Group USA.

Devi, M. (1993). "The Author in Conversation” in Imaginary Maps. Trans. Gayatri Chakravorty Spivak. Thema, Calcutta.

Gond, J. (2017, November 11). The identity of Adivasi Literature [Press release]. https://www.forwardpress.in/2017/11/the-identity-of-adivasi-literature/

Mbele, J. (1992). Language in African Literature: An Aside to Ngugi. Research in African Literatures, 23(1), 145-151. Retrieved from JSTOR.

Shekhar, H. S. (2017). The Adivasi Will Not Dance. Speaking Tiger. New Delhi.

Spivak, G. C. (1988). Can the Subaltern Speak? In C. Nelson \& L. Grossberg (Eds.), Marxism and the Interpretation of Culture (pp. 271-313). Urbana: University of Illinois Press.

Thiong'O, W. N. (1994). The Language of African Literature. In P. Williams \& L. Chrisman (Eds.), PostColonial Discourse and Post-Colonial Theory: A Reader (pp. 435-455). Columbia University Press.

Thiong'O, W. N. (1985). On Writing in Gikuyu. Research in African Literatures, 16(2), 151-156. Retrieved from JSTOR.

Tripathi, P. (2017). [Review Article: The Adivasi Will Not Dance: Stories, by Hansda Sowvendra Shekhar]. Rupkatha Journal on Interdisciplinary Studies in Humanities, 9(4), 193-196. https://dx.doi.org/10.21659/rupkatha.v9n4.ro2

Tudu, T. (2019). "They Eat Meat": A Study of Tribal Culture in Non-Tribal Vicinity. Research Journal of English Language and Literature (RJELAL), 7(3), 144-147. https://doi.org/10.33329/rjelal.73.144

Francis Ekka is a Research Scholar at the Department of English, Sikkim University. He is working in the area of Tribal Literature and Tribal Studies. His areas of interests are Gender studies, Queer studies and Tribal Studies. He has completed his MA from the Department of English, Sikkim University with First Class. He can be contacted at ekkafran@gmail.com.

Dr. Rosy Chamling is Associate Professor in the Department of English, Sikkim University, Gangtok, Sikkim. Her areas of interest are Literary Theory, Cultural Studies and Northeast Studies. She can be contacted at rchamling@cus.ac.in. 